\title{
The Advantages and Disadvantages of Arbitration in Relation to the Regular Courts in Kosovo
}

\author{
Valbon Mulaj*
}

\begin{abstract}
The purpose of this article is to identify advantages and disadvantages of arbitration in relation with regular courts in the Republic of Kosovo, in both the national and international aspect.

In general, arbitration is more flexible and provides more privacy than litigation. An arbitration case provides more privacy than litigation. Arbitration participants can agree to keep the final resolution and sensitive information completely private. The disputes arising in the arbitration may be identified and resolved by specialized professionals in the particular fields as the list of arbiters consists of those who have professional background in certain majors.

This article will be a comprehensive reference work on arbitration, considering that it has only been present in the Republic of Kosovo since 2010. In the framework of the institutional arbitration, the founding institutions of arbitration decide on the costs of the arbitration procedure so that the parties know the costs from the outset. Based on the decision on the costs of the arbitration procedure, the settlement of disputes in arbitration is less costly than in regular courts, as in some cases, court proceedings in regular courts last longer.
\end{abstract}

Keywords: arbitration, regular courts, advantages, disadvantages, Kosovo

\section{INTRODUCTION}

The aim of the paper is to present the advantages and disadvantages of arbitration versus court litigation. The advantages of arbitration are obvious and numerous as the arbitration is a private court and services are generally more effective and efficient.

Arbitration in the Republic of Kosovo, after the disintegration of the former Yugoslavia, was regulated by the Arbitration Regulation of $1999^{1}$ which was in force until promulgation of the Law on Contested Procedure of $2008,{ }^{2}$ providing several articles related to arbitration. In the same year (2008), the Kosovo Law on Arbitration, entered into force as the main law. ${ }^{3}$ Law on Contested Procedure and the Law on Arbitration were both in force as the two laws entered into force in 2008. This created a misinterpretation and a confusion regarding enforcement practice as some judges and arbitrators would call onto the Law on Contested Procedure and others onto the Law on Arbitration as the main law. However, the engagement of law experts resulted in the amendment of the Law on Contested Procedure and removal of the provisions and articles that regulate arbitration. When the Law on Contested Procedure entry into force in $2012,{ }^{4}$ the Articles related to arbitration in the Law of Contested Procedure of 2008 were removed. The amended Law on Contested Procedure does not regulate matters related to arbitration. In the Republic of Kosovo, arbitration is regulated by the Law on Arbitration of 2008, the Act for the Establishment of the

* Professor Assistant, Department of Civil Law, University of Prishtina - Faculty of Law, Agim Ramadani Str. p.n., 10000 Prishtina, Kosovo. E-mail: valbon.mulaj@uni-pr.edu

1 Regulation on Arbitration of the Kosovo Chamber of Commerce, 22 October 1999.

2 Law No. 03/L-006 on Contested Procedure (2008) link 14.

3 Law on Arbitration in Kosovo (2008) link 7.

${ }^{4}$ Law No. 04/L-188 on Contested Procedure (2012) link 8. 
Arbitration, ${ }^{5}$ Arbitration Rules, ${ }^{6}$ and the Decision on Costs of Arbitration Proceedings. ${ }^{7}$ Arbitration Establishment Act, Arbitration Rules, Decision on Costs of Arbitration Proceedings entered into force at the same time also in the Alternative Dispute Resolution Center of the American Chamber of Kosovo. If the arbitration procedure is conducted before these institutions in the Republic of Kosovo, all the aforementioned legal instruments apply and are binding as they were promulgated and made effective by respective institutions. Also, at the same time a list of arbitrators within Kosovo Chamber of Commerce, ${ }^{8}$ and the list of arbitrators under the American Chamber of Commerce in Kosovo $^{9}$ were created. If the parties agreed for different rules of arbitration, the proceeding may be conducted in accordance with the parties' agreement. However, if the parties did not agree on rules, the proceeding shall be carried out pursuant to official rules of arbitration before the Kosovo Arbitration Institution.

In this regard, special attention is paid to advantages and disadvantages of arbitration in relation to regular courts because they are overloaded in Kosovo. Arbitration is therefore one of the mechanisms enabling parties to resolve their disputes. This paper offers to the parties the opportunity to easily understand the advantages and disadvantages of arbitration vis-à-vis regular courts. These parties will then find it easier to have their dispute resolved in a better and more professional manner through arbitration than in regular courts.

\section{THE ADVANTAGES OF ARBITRATION IN RELATION TO THE REGULAR COURTS}

The advantages of arbitration are obvious and numerous because arbitration is in principle a private court, providing, in general, more efficient and faster services than regular courts. It resolves all disputes pertaining civil-legal and economic-legal requirements which may be subject to arbitration, unless prohibited by law. ${ }^{10}$ This may be substantiated by the approach of Harry T. Edwards that introduced

As a general proposition, I have found that the judicial process is heavily steeped in procedures. Many cases may be won or lost on 'procedural' points that have nothing whatsoever to do with the merits of the case. These procedural rules often are vitally important to preserve the integrity of the judicial process, but they also may obscure the real dispute between the parties. ${ }^{11}$

All disputes addressed to arbitration are resolved by specialized professionals of respective fields since only those who have a professional background in certain areas are registered in the arbitrators' list. In addition to professionalism, the appointed arbitrators must have authority and confidence in the country they live and operate in.

${ }^{5}$ Founder Charter of Permanent Tribunal of Arbitration in Kosovo Chamber of Commerce (2011) link 9.

${ }_{6}$ Rules on Arbitration in Kosovo (2011) link 10.

7 Decision on costs of arbitration proceedings in Kosovo Chamber of Commerce (2011) link 11.

${ }^{8}$ Kosovo Chamber of Commerce - List of Arbitrators (2014) link 12.

9 Alternative Dispute Resolution Center - List of Arbitrators (2015) link 16.

10 Article 5, paragraph 2 of the Law on Arbitration in Kosovo (2008) link 17.

11 Edwards (1982) link 18. 
Arbitration has many advantages in comparison to the regular courts.

They include

a. The parties choose the arbitrators themselves whom they fully trust, whilst for the disagreements resolved in state courts, the parties are unable to influence the judicial system ${ }^{12}$

b. The possibility of choosing arbitrators (judges) by the parties of their choice ${ }^{13}$

c. Reliability in arbitration

d. Efficiency

e. Confidentiality

f. Flexibility in selecting arbitrators and drafting of the rules of procedure

g. Expertise

h. Neutrality

i. The dispute resolution period

j. Arbitration decision in relation to decisions (judgments) of the regular courts

k. Price, in some cases, is cost-efficient

1. Arbitration as a mechanism for attracting foreign and domestic investment.

a) The parties choose the arbitrators themselves whom they fully trust, whilst for the disagreements resolved in state courts, the parties are unable to influence the judicial system $^{14}$

The appointment of arbitrators is considered of higher priority than the appointment of judges of the regular courts because in arbitration, to be chosen as arbitrator, the candidate must first have professional background and be a specialist in a field in order to be in a trusted position of arbitrator for settlement of disputes. The arbitrator, further to professional attributes, should have authority and be trusted to practice the profession of an arbitrator. Parties usually appoint arbitrators who are appointed within a particular institution, such as in Kosovo, from the list of arbitrators appointed under the Arbitration Tribunal of the Kosovo Chamber of Commerce and the Alternative Dispute Resolution Center within the American Chamber of Commerce in Kosovo.

Some of the conditions required for arbitrators in the Arbitration Tribunal of Kosovo Chamber of Commerce and the Alternative Dispute Resolution Center at the American Chamber of Commerce in Kosovo are:

i. To have a reputation and a high authority, as human and professional, to be entrusted the position of the arbitrator;

ii. To have completed a bachelor degree in the field of Law, Economics, Engineering, etc. in any of Universities in Kosovo or abroad;

iii. To have academic titles or senior experience in professional practice - academic titles are not a must, but a priority;

iv. To have demonstrated previously in another prior institution ethical, legal, professional attitude;

v. To be morally pure and politically neutral;

vi. Not to have been previously convicted for more than 6 months;

vii. To be over 30 years old;

12 Gorenc (2006) 305.

13 Baraliu (2010) 404.

14 Baraliu (2010) 305. 
viii. To have at least seven years of work experience;

ix. To have been interviewed before a professional committee and if in the interview successful, the candidate can be entered onto the list, they then have to complete the course, professional training, and then be certified as arbitrators.

The conditions and criteria for the selection of institutional arbitrators depend on institutions (Centers of Arbitration) and what selection criteria are set as it can be different from one place to another.

i) The conditions and criteria for selection of arbitrators (arbitration judges) are almost identical to regular courts, except that arbitration has an advantage because arbitrators must be more professional and must have proved themselves in the place where they live and where they operate in their profession.

ii) In the lists of arbitrators of Chambers of Commerce in Kosovo, from professional point of view, arbitrators have completed a bachelor degree in the field of Law, Economics, Engineering, etc. in any of Universities in Kosovo or abroad. All are specialized in specific areas. However, in the list of Chambers of Commerce in Kosovo, most arbitrators are lawyers each specializing in a particular subject area. ${ }^{15}$

iii) The arbitrators (arbitration judges) in most cases have academic titles. Although, academic titles are not a necessary criterion in arbitration, but are a big advantage.

iv) In professional terms, the arbitrator, once selected, enters the list of arbitrators, should be initially profiled regarding their profession, so that the parties, when checking the list of arbitrators, see professionalism, specialization of each and then be entrusted the case for resolution. ${ }^{16}$ Arbitrators, in the places where they worked before, should have proved to have done that job with honor, respecting the legal provisions and professional ethics.

v) Requirements of announcements for selection of arbitrators in Kosovo provide that candidates shall not be members of any political party, in order to ensure trust of the parties toward arbitrators. ${ }^{17}$

vi) It is required that the arbitrator must not have been previously convicted for more than 6 months, as in any other institution where is required when applying for employment, it should be declared if they have been convicted of a criminal offense, imprisonment sentence for more than 6 months. Even in arbitration, it is required in order to ensure the institution, the arbitrator, who wants to work as an arbitrator has not committed a criminal offense punishable with more than 6 months.

vii) An arbitrator it is required to be over 30 years old; it is considered that they are mature and suitable to exercise this position with dignity, endurance, reliability and high professionalism. ${ }^{18}$

viii) Work experience of at least 7 years is required in order to be selected as arbitrators. This results in the person being professional in position which they perform as arbitrators and to be persuasive to the parties. ${ }^{19}$

15 In the list of arbitrators of the Arbitration Tribunal of Kosovo Chamber of Commerce, of 27 arbitrators, who are seen on the list, at least 21 (twenty-one) of them are lawyers (2014) Link 12.

16 Interview of Mr. Visar Ramaj, Secretary of the Centre of Arbitration in The American Chamber of Commerce in Kosovo, date 17 June 2014.

17 Kosovo Chamber of Commerce (2015) link 19.

18 This condition was required in the competition for the selection of arbitrators/Arbitration Tribunal of the Kosovo Chamber of Commerce.

19 The same was required in the application for the selection of arbitrators/Arbitration Tribunal of the Kosovo Chamber of Commerce. 
ix) If a candidate has fulfilled the conditions defined by the announced call for arbitrators, they are then invited for an interview. Professional and educational documents introduced by the candidates shall be examined by the professional selection board consisting of the Chairman of the Center of Arbitration, Secretary of the Center of Arbitration and an experienced arbitrator.

$\mathrm{x})$ A successful interview results in the candidate being added the arbitrators' list. They must then complete a professional training organized by the founding institution of arbitration. The professional training are organized for those candidates who have demonstrated success in all phases of their choice and the training is further professionalize the candidates for arbitration, help them in the selection of the most the suitable practice in their work; be informed about the best models of the functioning of arbitration in many developing countries, so that they, under the law, appeal to those services as the best ones for the parties.

\section{b) The possibility of choosing arbitrators (judges) by the parties ${ }^{20}$}

Parties have the right to choose themselves the sole arbitrator or arbitrator body consisting of three members. Parties agree as to the number of arbitrators, each party proposes and selects one arbitrator. These two arbitrators then choose the third arbitrator, who then chairs the arbitrators in the arbitration session.

After taking the resume of arbitrators who are selected and added to the list of arbitrators of Kosovo Chamber of Commerce, American Chamber of Commerce or any other Chamber of Commerce, which operates in Kosovo, or another state, shall appoint the best professional candidate. Arbitrators must, after appointment by the parties, be approved by the founding institution of arbitration. Arbitrators appointed by the parties, should be completely independent, show professionalism and determination in the award, have high professional and moral integrity in making the decision.

Parties, along with selected arbitrators agree on the dispute resolution period, the place of the session, the language of the arbitration, certain laws to resolve the dispute, the number of professional experts, witnesses, representatives of parties and the record-keeper. They agree whether the arbitration sessions be recorded and whether an arbitral award should be with or reasoning. As a rule, all arbitral awards have to be reasoned, because by reasoning the parties agree and abide to the award. However, in cases where the parties request that the arbitral award be taken without reasoning, then the sole arbitrator or body composed of three arbitrators should act as parties request and desire. In practice, such cases are rare, but the important thing is that arbitrators are careful to present the best forms of awards.

The arbitral award has no degrees of instances. Shortly after publication, it goes to the execution of the award. In principle, the procedure is conducted through one instance, i.e., without appeal, which also affects the acceleration of the final award. ${ }^{21}$ The award can be only be appealed if it is verified that it was awarded as a result of legal or procedural violations.

Court proceedings in regular courts are conducted depending on the load of the judge and the concerned parties cannot decide, nor can interfere with this matter in court. Parties cannot decide on the language nor the place and the law, because such is provided in the 
Law on Courts in Kosovo ${ }^{22}$ and the Law on Contested Procedure. ${ }^{23}$ Also, the parties in regular courts cannot decide on the form and content of the decision. They cannot require that the decision be reasoned and decide to have the time for making the decision. Such a thing can be asked and realized as the free will of the parties to arbitration and here is seen that arbitration has more rights than regular courts about the advantages of parties in civil and commercial disputes.

\section{c) Credibility in arbitration}

Arbitration has, as one of its main goals, credibility. To ensure and achieve success in legitimate defense of businesses which entrust their disputes to arbitration, after the arbitral award, the parties should be satisfied with the performance of arbitrators. For businesses, arbitration is considered as their favorite for the resolution of disputes by arbitration between them. Credibility is achieved if the arbitrators are never influenced from outside and have not violated procedures in any case, and have not given an award if they were in conflict of interest, also have not agreed to be part of the panel, if they have not been professional in the context of trust given by the parties. Credibility is also created if the Tribunal (Arbitration Centers) creates contacts and good cooperation, both with parties, businesses as well as with arbitrators who settle the dispute of the parties, businesses. Arbitration proceedings, holding of sessions, and decision making process are speedier than in regular courts. This makes the parties have more trust and a greater interest in arbitration that some or all of their disputes are entrusted to arbitration settlement. Arbitration proceedings are held as non-public and without the presence of the public, citizens, whereas, regular court hearings are held in public and anyone who has an interest and desire can attend.

\section{d) Efficiency}

Efficiency in the arbitration is a positive indicator throughout the arbitral proceedings, starting with the first meeting with the parties after the appointment as an arbitrator, during the preparatory session, the main hearing, until the final decision.

Commercial disputes resolution between businesses in Kosovo has started, although not in large numbers as desired to be done through Arbitration Centers, which operate within the Kosovo Chamber of Commerce and the American Chamber of Commerce in Kosovo. In the future, businesses will address themselves more to arbitration to resolve their disputes as a result of economic efficiency of work which arbitrators do under the Arbitration Center. Parties consider arbitration more efficient for resolution of their disputes starting from the initial communication with institution of arbitration as well as with arbitrators assigned for resolution of their dispute. Arbitrators from the very beginning provide parties with many rights related to their disputes such as parties may decide for the timeline to resolve their dispute, for the place where the resolution procedure is to be conducted and for the language to be used during the resolution procedure.

\section{e) Confidentiality}

Unless the parties expressly agree in writing to the contrary, the parties undertake, as a general principle, to keep secret all decisions and orders and all materials submitted by

22 Law Nr. 03/L-199, on Courts in Kosovo (2010) link 13.

${ }^{23}$ Law Nr. 03/L-006 on Contested Procedure in Kosovo (2008) link 14. 
another party within the arbitral proceedings. These rules apply to all participants who take part in the arbitration proceedings as well as participants of the Arbitral Tribunal. The participants are the Arbitral Tribunal arbitrators participating in the body composition and the record-keeper if, in fact, agreed by the parties and arbitrator body of the recordkeeper. Other participants may be the claimant, the respondent, attorneys, consultants, experts and witnesses.

If institutional arbitration confidentiality is foreseen, the parties, if agreed upon, must sign a declaration of confidentiality. It is the obligation of the arbitrator or Body of arbitrators at the beginning of the meeting to inform the parties and to propose that all actions, starting from the preliminary hearing, and the main decision, be confidential. If the parties agree, they should also be introduced to the responsibilities of the parties in case of breach of confidentiality.

In such case, the confidentiality statement must be signed by the record-keeper, who holds the record during the arbitration hearing. In arbitration, initially, the body of arbitrators must obtain the approval of the parties to maintain a record of the process and also have the record-keeper then sign a declaration of confidentiality. If the parties request that the recordkeeper initially signs a statement of confidentiality, they must sign it as the parties, businesses, unless it is not provided in the arbitration rules of confidentiality. Whereas, if the arbitration rules provide confidentiality as a necessity, then it is not necessary to sign a declaration of confidentiality neither by the parties nor by the record-keeper, because it is known from the beginning that any procedural action is confidential for all participants.

Confidentiality is a priority in relation to the regular courts because even the losing party or business, does not lose authority or professional reputation, because the decision is not made public, unlike in the regular courts where all decisions, judgments are public and every citizen, party, business can see those decisions, judgments of regular court. For the party or business which lost the dispute, its business and market may get endangered because others may have fear or prejudice to the seriousness of the cooperation with that certain business. Such a thing in arbitration is kept safe and not made public. The damaged party realizes this request, the compensation required under the claim, and also the losing party does not lose prestige and confidence to establish cooperation with other businesses, because the loss of the dispute is not made public and is not known to have been guilty of non-fulfillment of contract with another business.

\section{f) Flexibility in selecting arbitrators and drafting of the rules of procedure}

Flexibility in arbitration is much greater than in regular courts because the parties in arbitration decide on the appointment of arbitrators and the arbitration rules. Also, if the parties agree, they can avoid a certain order, and in accordance with each other, may agree to another rule, only when there is agreement among them. The arbitrators shall, after consultation with the parties, decide on the procedure. All these make arbitration more flexible than regular courts.

\section{g) Expertise}

Unless the parties have agreed otherwise, the arbitral tribunal may appoint one or more experts to report to it in writing on certain issues from the Arbitration Tribunal. ${ }^{24}$ It is not meant that the arbitrator or Body of arbitrators understand everything required by the 
parties. If needed, experts can be hired to such issues and they, through their expertise, provide the expertise report for which they are engaged as experts.

The arbitrator or body of arbitrators when issuing the award, to justify the arbitral award, mention the expertise provided by the expert to which the parties and body of arbitrators agreed on expertise of by appointing them to resolve the dispute between the parties.

\section{h) Neutrality}

The arbitrators, although nominated and appointed by the parties, are neutral throughout the arbitral proceedings, as well as on the decision on award. The arbitrators, although appointed by the parties are not able to support one party outside the law and rules of arbitration. The parties shall appoint arbitrators because they have adequate professionalism, have greater credibility to them, and not to support a party outside the law or the rules of arbitration.

\section{i) Dispute settlement period}

Apriority in arbitration is the dispute settlement period. The parties shall determine the period of dispute settlement and at their request, the sole arbitrator or body of arbitrators shall consider the time whether are free to hold hearings within the parties' request and to take the arbitral award within that period. And if they are available, they inform the parties that they agree to their request and can make the decision within the required time. Parties in a particular dispute, if they agree, are able to resolve their dispute within one month, three months, six months, a year at most, depending on their will, how they require from a sole arbitrator or Body of arbitrators to resolve their dispute. If the parties so require, it can be extended over the period limit, because this freedom is given to the parties, although in practice this kind of demand is or may be rare, as most of the requests are from the claimant to end dispute as soon as possible. The advantage of arbitration is the speed of dispute resolution. Dispute settlement period is determined in cooperation with the parties, businesses, in consultation with the arbitrator or body of arbitrators. Such a thing cannot be done in regular courts because courts operate according to their own agendas and it is known that in practice that they all have an overloaded agenda. They have many unsolved cases and those carried forward from one year to another where the will of consent of the parties is not free as in arbitration.

Dispute settlement period (days) in the regular courts are distinguished from arbitration because arbitration uses the will of the parties. In the Commercial Court, a settlement of the dispute lasts 420 days, while the same in Arbitration Centre of the Kosovo Chamber of Commerce, lasts 215 days. On this basis, arbitration has advantages for businesses in relation to the regular courts. In arbitration, parties benefit much more time, because they finish 205 days faster the case than in the regular courts. ${ }^{25}$

In the 2012 annual report of the Kosovo Judicial Council, the administration of regular courts, a key component of court restructuring, included the transfer of more than 240,000 cases from the current courts to newly established courts, ${ }^{26}$ while the value of these dispute cases is 250 million euros. ${ }^{27}$ Kosovo Judicial Council, in August 2013, drafted the National

25 Kosovo Chamber of Commerce (2015) link 20.

26 Judicial Council of the Republic of Kosovo (2012) link 21.

27 Greer, David, 'Put it on paper', Round table discussion on the importance of contracts and alternative dispute resolution, Conference organized by the American Chamber of Commerce in Kosovo, date November 01, 2013. 
Strategy to Reduce Backlog Cases, where a strategic objective was the greater reduction of cases that are transferred from year to year. This strategy includes cases which are classified 'as old' and those cases which will become 'old' if no action is taken in time for their resolution/closing. ${ }^{28}$ Kosovo Judicial Council (KJC) under Article 108 of the Constitution of the Republic of Kosovo, Article 4, para. 1 sub-par.1.15, of Law no. 03/223 for the Kosovo Judicial Council, at its meeting held on the 6th September 2013, with the decision number 86/2013, issued this decision, the decision on the approval of the National Strategy to Reduce Backlog Cases. ${ }^{29}$ Strategy defines already old cases as cases that were filed before 2012, meaning all cases to 31 December 2011. ${ }^{30}$ Until August 2013, approximately 142,000 cases are defined as old, including approximately 91,000 cases in execution. ${ }^{31}$ In virtue of the aforementioned information, the regular courts are overloaded with numerous cases filed on daily basis, to include carried over from year to year and arbitration could help regular courts in resolving civil-commercial disputes.

Parties in proceedings attempting to resolve their dispute through regular courts may suffer profit loss and bankruptcy due to prolongation of court proceedings. Even if the winning party is awarded with indemnity, the amount of indemnification may not recover the business consequences. Arbitration is definitely a better option as the same dispute would be resolved faster and protect the party's interest.

\section{j) The arbitral award in relation to decisions (judgments) of regular courts}

The arbitral award in relation to the regular courts, is more voluminous, ${ }^{32}$ more detailed, because in every issue is discussed reasoning and noted any evidence so that the parties are in no doubt about the decision, while the regular court decisions (judgments) are much shorter and are not releasing many specific details in the reasoning. ${ }^{33}$ Presentations of experts associated with practice of arbitration are introduced in this award: Fraport AG Frankfurt Airport Services Worldwide v. Republic of the Philippines (ICSID Case No. $A R B / 03 / 25) .{ }^{34}$ The regular court practice may be presented by the following decisions of the Supreme Court: Rev. No. 11/2005, 16 November 2005; Rev. No. 33/2007, 19 March 2009; Rev. No. 172/2006, 1 August 2007; Rev. No. 179/2006, March 25, 2008; Rev. No. 290/2007, 16 March $2010 .{ }^{35}$ Herewith, decisions of regular courts are not very long - a maximum of six pages, including introduction, enacting clause, and reasoning of the award. While in

28 National Strategy for the Reduction of Backlog Cases (2013) link 22.

${ }^{29}$ Decision on Approval of the National Strategy for the Reduction of Backlog Cases (2013) link 23.

30 National Strategy for the Reduction of Backlog Cases (2013) link 22.

31 National Strategy for the Reduction of Backlog Cases (2013) link 22.

32 Kotuby (2014) link 24.

33 Rev. nr. 270/2007, 20 May 2010 Case Law Bulletin. The Supreme Court, Volume 1, Project funded by the EU and managed by the European Commission Liaison Office and Kosovo Law Center, Pristina, 2011, p. 135.

${ }^{34}$ Fraport AG Frankfurt Airport Services Worldwide v. Republic of the Philippines (ICSID Case No. ARB/03/25) (2007) link 4.

35 See these civil decisions: Rev. Nr. 11/2005, 16 November 2005, p. 123-26; Rev. Nr. 33/2007, 19 March 2009, p. 130-34; Rev. Nr. 172/2006, 01 August 2007, p. 139-42; Rev. Nr. 179/2006, 25 March 2008, p. 143-48; Rev. Nr. 290/2007, 16 March 2010, p. 153-55, Case Law of BGJK Bulletin, Volume 1, This publication was produced by the Twinning, Reform of Legal Education System, Supreme Court, summarized and edited by Kosovo Law Center. This publication was published with the support of the European Union and the Government, published in 2011. 
arbitration the practice has proved that a decision no matter how simple and not complicated is, has a minimum of 10 pages and not to mention about other cases that the decision could be well over $50^{36}$ or over $100^{37}$ pages.

Parties or businesses, if they have a contract and the contract provides the arbitration clause, are obliged to settle their dispute in Arbitration Tribunal. If one party submits a claim in the regular courts, the latter are obliged to refer the parties to arbitration, because the arbitration tribunal is competent. If the parties to the contract entered, have provided the arbitration clause, the case is referred to arbitration. If a party disagrees and refuses to participate in the arbitration proceedings, arbitration begins with arbitration proceedings in the absence of a party, a same decision is issued to the party as having taken part in the arbitration session, which means that a party that has filed the claim in the arbitration Tribunal, under the arbitration clause provided in the contract which both parties have signed, cannot be damaged and be the victim. Therefore, arbitral award is taken in the absence of one party.

\section{k) Price, in some cases, is cost-efficient}

Price, in some cases, is cost-efficient in arbitration than in a regular court, and this happens because the arbitration dispute is resolved more quickly, efficiently and at a faster procedure, sessions do not last long as in regular court. The price is cheaper because the dispute is resolved quickly with no high fees for lawyers, as a result of the length of sessions; Arbitration sessions usually involve lawyers of businesses and do not incur costs. In addition, the preparation of the memorials is also a crucial issue. In arbitral procedure, the parties agreed upon the procedure, where the costly preparation of numerous memorials can be missing, they did not consider them as crucial in the procedure.

\section{l) Arbitration as a mechanism for attracting foreign and domestic investment}

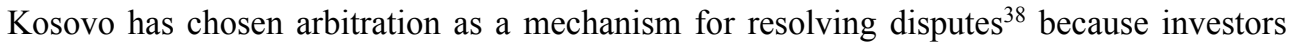
have request such a thing in the first contacts made with competent institutions and local businesses. The investors ask about how much the foreign investor is ensured and protected; the state of operation of the regular courts is and how arbitration functions in this country.

In addition, it is important for investors to know what the purpose of the law on investment is in the country where they wish to invest. The purpose of the law on foreign investment in Kosovo says it should offer and guarantee to foreign investors basic rights that give assurance to foreign investors that their investments be protected and treated fairly in accordance with the standards and internationally accepted practices. ${ }^{39}$ Parties or businesses require such a thing so early in order to know the purpose of investment and arbitration in that place, as it is much easier to accept and apply such a thing in practice.

36 Date of dispatch to the parties: 29 April 1999. AWARD in the Arbitration ARB/94/2 of the International Centre for Settlement of Investment Disputes (ICSID) (1999) Link 25.

37 Date of dispatch to the parties: May 22, 2007. International Centre for Settlement of Investment Disputes Washington D.C. in the proceedings between Enron corporation ponderosa assets, 1.p (claimants) and Republic of Argentine (respondent) ICSID Case No. ARB/01/3. Award (2007) Link 26.

38 Muharremi (2009) 2.

39 Law no. 04/L-220 on Foreign Investment in Kosovo (2014) link 3. 
The main purpose of the Law is to promote and encourage foreign investment in Kosovo, offering foreign investors the basic rights and enforceable guarantees which give them assurance that these investments will be protected and will be treated fairly and in full compliance with the principle of the rule of law and internationally accepted standards and practices. $^{40}$

Parties in a foreign investment, may specify any arbitration proceeding or settlement of disputes, for which they may agree. ${ }^{41}$ Foreign investors not only require stability and legal certainty, they also require a consistent and reliable and impartial, professional and efficient mechanism in dispute resolution. ${ }^{42}$ Such credibility can be considered only in arbitration, which is considered very favorable, and with great advantage for businesses. Foreign investors operating in the region, but not in Kosovo, cited three main reasons behind their disinterest for business development in Kosovo: unfavorable legal infrastructure, fighting bureaucracy and a lack of fiscal stimulus. ${ }^{43}$ Foreign investors have little confidence in local courts, particularly when dealing with large projects and significant infrastructure. ${ }^{44}$ In 2010, Kosovo has made significant improvements in terms of legal infrastructure and combating bureaucracy, raised by foreign investors, as well as improving the ranking confirms the World Bank Report on Doing Business in 2013. ${ }^{45}$ Kosovo, with regard to its legal infrastructure, has significantly improved and all laws drafted take into account the European standards and are increasingly being adapted to circumstances in the country.

However, the American Chamber notes that more needs to be done in terms of solving the third problem raised by potential foreign investors, the lack of adequate fiscal incentives. ${ }^{46}$ This is the main reason why foreign investors usually support international arbitration as a mechanism for resolving disputes with host country. ${ }^{47}$ Kosovo should become part of a vast network of bilateral treaties and multilateral investment by specifying protection standards ${ }^{48}$ in order to have more agreements about arbitration. Currently, there are more than 2,200 agreements (Bilateral Investment Treaties), involving 176 different countries. Moreover, there are other agreements dealing with investment protection, including the North American Free Trade Agreement (NAFTA), European Energy Treaty (EET). ${ }^{49}$ Kosovo should take into account that foreign or domestic investors want their disputes or disagreements resolved better and professionally by arbitration, whether domestic or international, depending on the agreement established between the parties, at the time of contract. Foreign investors must be convinced and assured that arbitration in Kosovo works very well and quickly, is professional and gives complete freedom to the parties to decide to resolve their dispute in national or international arbitration.

40 Law No. 02/L-33 on Foreign Investment in Kosovo (2006) link 2.

41 Brestovci (2002) 58.

42 Muharremi (2009) 2.

43 Hapçiu and Ramaj (2013) 3.

44 Muharremi (2009) 2.

45 Hapçiu and Ramaj (2013) 4.

46 Hapçiu and Ramaj (2013) 4.

47 Muharremi (2009) 2.

48 Hapçiu and Ramaj (2013) 14.

49 Bishop and Crawford (2005) 10. 


\section{THE DISADVANTAGES OF ARBITRATION IN RELATION TO THE REGULAR COURTS}

Arbitration has not only advantages but disadvantages and some of the disadvantages of arbitration in relation to the regular courts are:

1. Non qualified arbitrators

2. Lack of credibility

3. There is no second instance in arbitration

4. Arbitration is a secondary job ${ }^{50}$

5. Potential corruption of the arbitrator or Body of arbitrators.

\section{Non-qualified arbitrators}

If the appointment of arbitrators is not made on legal grounds and conditions that are set out in the vacancy, but with political, family influence, who also have the conflict of interest in the exercise of their profession results in the arbitrator lacking professionalism in the position exercised.

Any appointment of arbitrators by the institution which appoints them, if appointed as a result of external influences, then arbitration, from the beginning, appears to be established in a negative way and cannot work smoothly. Arbitration differs from regular courts precisely because arbitrators are selected experts in certain fields. In the event that their appointment is not made on that basis, then it may be not so successful.

This type of arbitration operation by the parties, businesses, can be considered as nepotism causing lack of confidence believe in justice and dispute resolution in a professional way, because professional arbitrators and experts have not been selected.

\section{Lack of credibility}

In the initial establishment of arbitration has its difficulties, because it is challenging for establishing professionals. However, professionals, to have reliable arbitration from the establishment should be careful, since the act of incorporation, drafting of arbitration rules, the costs of the arbitral proceedings, the appointment of arbitrators conducted on the basis of best practices of developed countries. The commitments of the Kosovo Chamber of Commerce and the American Chamber of Commerce in Kosovo, together with the USAID, have invested in quality and awareness on role and importance of arbitration in Kosovo and outside, regarding its advantages and disadvantages. The endeavors of these two institutions have had a crucial impact on local businesses to change the mentality of the past that their contests may not be resolved by regular courts only. The arbitration is another possibility for dispute resolution.

\section{There is no second instance in arbitration}

Sometimes, parties consider to their detriment having no second instance to appeal decision rendered by arbitration. They cannot challenge from higher instance and therefore think that

${ }^{50}$ If we analyze the list of arbitrators of the Arbitration Tribunal in Kosovo Chamber of Commerce, we see that most of them, almost all at the same time have a regular working relationship and, besides that relationship arbitrators exercise the professions. Taking into account the nature of the arbitrator, it is understood that it is normal and logical to have another employment relationship (2014) Link 12. 
the regular state courts are more favorable and of more interest, to cover the true reliability and resolution of the case.

For the countries in transition such as Kosovo, parties are expected to hesitate to believe in resolution of disputes by arbitrators, as they may find them biased. Parties may still prefer judges from regular courts, which are required to be impartial, confident, reliable and accountable by law. Lacking of confidence towards arbitrators is because arbitration is a new way of dispute resolution among parties. The high instances of regular court can be more credible because the parties always think that the highest instance courts such as the Court of Appeal, the Supreme Court, after the appeal from the parties may change the decision of the first instance court. There are cases when businesses who know they are going to lose their dispute to arbitration, want to take the case to regular court and delay the procedure, so that the obligations and benefits that have to be made to the other party (other business) be done at a later period and with those funds (money) circulate in their business for a certain time. This is always the case when parties do not have an arbitration clause in the contract.

\section{Arbitration is a secondary job ${ }^{51}$}

Another drawback of arbitration in relation to the ordinary courts is that regular court judges is a profession which they exercise - it is fulltime employment. Regular court judges are not allowed to have two working relationships at the same time, only if they are invited for some training so that their knowledge of multi-year work can bring knowledge to others or hold lectures at the Law Faculty of public or private universities after obtaining permission from the Kosovo Judicial Council.

This is different for arbitrators, as in addition to their fulltime work, working with normal working hours, engagement with arbitration is secondary employment outside normal working hours. Although arbitration as a strong point has the consent of the arbitrator with the party or parties claiming, which means that if the arbitrator does not have the time and/or expertise and/or desire for the proposal made by the parties to resolve the dispute, the arbitrator can then reject the proposal and the parties nominate another arbitrator.

\section{Potential corruption of the arbitrator or Body of arbitrators}

If it happens that an arbitrator under the Arbitration Tribunal in Kosovo Chamber of Commerce is corrupted, then the credibility of arbitration is rather weakened with negative effects. Arbitration credibility has an important role and is considered one of the main purposes of the arbitration. Even in the regular courts, corruption is treated as very negative and adversely affects the overall image of the judiciary. This flaw does not affect much as in arbitration, because the regular courts still must resolve the dispute in regular court, if not provided the arbitration clause. Whereas, in arbitration, parties may lose their confidence completely.

In arbitration, if a corrupted arbitrator is not discharged and is not taken the certification as an arbitrator from the arbitration center, it is sanctioned by the parties because they do

51 If we analyze the list of arbitrators of the Arbitration Tribunal in Kosovo Chamber of Commerce, we see that most of them, almost all at the same time have a regular working relationship and, besides that relationship arbitrators exercise the professions. Taking into account the nature of the arbitrator, it is understood that it is normal and logical to have another relationship work (2014) Link 12. 
not name it in their disputes. While in the other types of ad hoc, accelerated or specialized arbitration, the authority of the arbitrator or arbitrators is mostly affected. If the body of arbitrators was composed of three members, they lose authority, professionalism, reliability in resolution of commercial disputes in the state in which they operate, but also in other countries, because the information circulates in various forms as the party which wishes to propose them as an arbitrator in resolving the commercial dispute, is primarily recommended to study their biography, completed cases, and success in those cases. If ever affected by one party, or political influence, or has been corrupted and their personality sometimes is questioned the credibility of the case.

\section{CONCLUSIONS}

After the war in Kosovo, many foreign investors have been interested to invest in various sectors but foreign investors have seen the challenge that Kosovo has with consolidation of its institutions after the war, as an obstacle. Therefore, their initial enquiry was raised whether arbitration is available in Kosovo as an alternative mean of resolution of possible disputes.

Having arbitration available in the state legal system enables foreign investors to believe their business is safe and that process of operation is not interrupted or affected.

The establishment of institutions related to arbitration in Kosovo and adoption of respective legislation has provided both, domestic and foreign investors with legal protection towards exercising their business activities.

Only by providing legal guarantees for foreign investors, making Kosovo a safe trade environment will make possible economic development and improvement of welfare for its citizens. As a conclusion, this paper has intended to elaborate and distinguish arbitration as a legal method for resolution of civil - legal and commercial disputes especially in Kosovo.

\section{LITERATURE}

Baraliu, Mazllum, Business Law (University of Prishtina 2010).

Bishop, Doak and Crawford, James, Foreign Investment Disputes (Kluwer Law 2005).

Brestovci, Faik, 'Regulation no. 2001/3 for Foreign Investments in Kosovo' (2002) 3 Social Judicial Affairs Magazine, Law, Pristina, 37-60.

Center of American Chamber of Commerce in Kosovo, FDI for economic growth - Alignment with the region in attracting more foreign investment in Kosovo (September 2013).

Centre for Alternative Dispute Resolution of the American Chamber of Commerce in Kosovo (ADR Center), Enforcing arbitral awards and mediation agreements, date March 20, 2014. $<\mathrm{http}: / / \mathrm{www}$. adr-ks.org/site/shenimet/files/5906/ancham_adr_center_-_call_for_arbitrators_final-1.pdf> accessed 12 June 2015.

Gorenc, Vilim, Fundamentals of commercial statutory and contractual law (University College 'Victory' 2006).

Greer, David, 'Put it on paper' in Round table discussion on the importance of contracts and alternative dispute resolution (Conference organized by the American Chamber of Commerce in Kosovo 1th November 2013).

Hapçiu, Visar and Ramaj, Visar, FDI for economic growth - Alignment with the region in attracting more foreign investment in Kosovo (report, 2013).

Kosovo Law Center, (2011) 1 Bulletin of Judicial Practice, Kosovo Supreme Court 180-82.

Muharremi, Robert, Foreign investment (EMSG-Stability and Growth Management) (USAID 2009).

Ramaj, Visar, Interview of Secretary of the Centre of Arbitration in The American Chamber of Commerce in Kosovo (17 June 2014).

Regulation on Arbitration of the Kosovo Chamber of Commerce, 22 October 1999. 
Rev. nr. 270/2007, 20 May 2010 Case Law Bulletin. The Supreme Court, Volume 1, Project funded by the EU and managed by the European Commission Liaison Office and Kosovo Law Center, Pristina, 2011, p. 135.

See these civil decisions: Rev. Nr. 11/2005, 16 November 2005, p. 123-26; Rev. Nr. 33/2007, 19 March 2009, p. 130-34; Rev. Nr. 172/2006, 01 August 2007, p. 139-142; Rev. Nr. 179/2006, 25 March 2008, p. 143-48; Rev. Nr. 290/2007, 16 March 2010, p. 153-55, Case Law of BGJK Bulletin, Volume 1, published in 2011.

\section{LINKS}

1. Kosovo Judicial Council (2014) <www.gjyqesori-rks.org> accessed 04 December 2014.

2. Law No. 02/L-33, under Article 1, para. 1 of the Law on Foreign Investment in Kosovo, which entered into force on 28 April 2006, Official Gazette of the Republic of Kosovo (2006) <http:// gazetazyrtare.rks-gov.net/Documents/7\%20(shqip).pdf $>$ accessed 07 December 2014.

3. Article 1 of Law no. 04/L-220 on Foreign Investment in Kosovo, 2014, Official Gazette of the Republic of Kosovo (2014) <http://gzk.rks-gov.net/ActDetail.aspx?ActID=8982> accessed 12 January 2015.

4. Fraport AG Frankfurt Airport Services Worldwide v. Republic of the Philippines (ICSID Case No. ARB/03/25) (2007) <http://italaw.com/sites/default/files/case-documents/ita0340.pdf $>$ accessed 15 January 2015.

5. Law No. 03/L-006 on Contested Procedure, 2008. Official Gazette of Republic of Kosovo (2008) $<$ http://gzk.rks-gov.net/ActDetail.aspx?ActID=2849> accessed 22 December 2014.

6. Regulation on Arbitration of the Kosovo Chamber of Commerce (2011) <http://www.kosovoarbitration.com/page/arbitrationrules> accessed 17 January 2015.

7. Law on Arbitration in Kosovo, entered into force on 05 June 2008. Official Gazette of Republic of Kosovo (2008) <http://gzk.rks-gov.net/ActDetail.aspex?ActID=2579> accessed 17 January 2015.

8. Law No. 04/L-188 on Amendments and Changes of Law No. 03/L-006 on Contested Procedure, 2012. Official Gazette of Republic of Kosovo (2012) <http://gzk.rks-gov.net/ActDetail. aspx?ActID=2849> accessed 19 January 2015.

9. Founder Charter of Permanent Tribunal of Arbitration in Kosovo Chamber of Commerce. Entered into force on 24 June (2011) <http://www.kosovo-arbitration.com/uploads/files/Akti\%20 themelues.pdf $>$ accessed 19 January 2015.

10. Rules on Arbitration in Kosovo, entered into force on 24 June (2011) Retrieved from $<\mathrm{http} / / /$ www.kosovo-arbitration.comuploads/files/Rregullat\%20e\%20Arbitrazhit.p > accessed 19 January 2015.

11. Decision on costs of arbitration proceedings in Kosovo Chamber of Commerce. Entered into force in $(2011)<\mathrm{http} / /$ www.kosovo-arbitration.com/uploads/files/Shpenzimet\%20e\%20Procedurws.pdf $\$$ accessed 27 January 2015.

12. Kosovo Chamber of Commerce - Kosovo Permanent Tribunal of Arbitration. List of Arbitrators. (2014) <http://www.kosovo-arbitration.com/lista-e-arbitrave> accessed 15 December 2014.

13. Law No. 03/L-199, on Courts in Kosovo, entered into force (2010) <http://gazetazyrtare.rks-gov. net/Documents/Ligji\%20per\%20Gjykatat\%20(shqip).pdf $>$ accessed 15 December 2014.

14. Law No. 03/L-006, on Contested Procedure in Kosovo, entered into force in (2008) <http:// gazetazyrtare.rks-gov.net/Documents/shqip-9.pdf> accessed 15 December 2014.

15. Article 25, para. 1 of the Law on Arbitration in Kosovo, in 2008, Official Gazette of Republic of Kosovo, (2008) <http://gzk.rks-gov.net/ActDetail.aspx?ActID=2579> accessed 19 January 2015.

16. Alternative Dispute Resolution Center - List of Arbitrators (2015) <http://www.adr-ks.org/ arbitrators/> 19 January 2015.

17. Article 5, paragraph 2 of the Law on Arbitration in Kosovo, which entered into force in 2008, p. 2.

18. Edwards, Harry T., 'Advantages of arbitration over litigation: reflection of a judge'. p.24. (1982) $<$ http://www.naarb.org/proceedings/pdfs/1982-16.pdf> accessed 22 December 2014.

19. Kosovo Chamber of Commerce (2015) <http://www.adr-ks.org/site/shenimet/files/5906/ancham adr_center_-_call_for_arbitrators_final-1.pdf $>$ accessed 19 January 2015. 
20. Kosovo Chamber of Commerce (2015) <http://www.adr-ks.org/site/shenimet/files/5886/amcham adr_center_catalog.pdf $>$ accessed 19 January 2015.

21. Judicial Council of the Republic of Kosovo, Annual Report 2012, p. 20 (2012)<http://www.kgjkks.org/repository/docs/raporti_final_ALB 2012 725938.pdf> accessed 02 February 2015.

22. National Strategy for the Reduction of Backlog Cases, August 2013, p. 2 (2013)<http://www. kgjk-ks.org/repository/docs/final---backlog-reduction-strategy-(3)-ALB_846866.pdf > accessed 02 February 2015.

23. Decision on Approval of the National Strategy for the Reduction of Backlog Cases, the number of decision 86/2016, on 06 September, 2013. This decision was taken by the Kosovo Judicial Council (2013) < http://kgjk-ks.org/repository/docs/Vendimi-86_80769.pdf> accessed 02 February 2015.

24. Kotuby, Charles, News and Views in Private International Law. 'Intellectual Whiplash', One Day, Two International Cases, And Two Different Results At The U.S. Supreme Court. on 09 March 2014, in Conflict of Laws. (2014) <http://conflictoflaws.net/2014/intellectual-whiplash-one-daytwo-international-cases-and-two-different-results-at-the-u-s-supreme-court/> accessed 19 January 2015.

25. Date of dispatch to the parties: 29 April 1999. AWARD in the Arbitration ARB/94/2 of the International Centre for Settlement of Investment Disputes (ICSID). Tradex Hellas S.A. (Greece) represented by Mr. E. Counsel, Koronis, Prof. L. Georgakopoulos vs. Republic of Albania represented by the Ministry of Agriculture and Food which was represented by Ms. Rezarta Gaba by Mr. Sali Metani and by Ms. Julinda Hajno Counsel: Prof. James Crawford Mr. Philippe Sands by the Arbitral Tribunal consisting of, Prof. Dr. Karl-Heinz Böckstiegel, President, Mr. Fred F. Fielding, Esquire, Arbitrator, Prof. Andrea Giardina, Arbitrator Date of Award (1999) <http:// italaw.com/sites/default/files/case-documents/ita0871.pdf> accessed 19 January 2015.

26. Date of dispatch to the parties: May 22, 2007. International Centre for Settlement of Investment Disputes Washington D.C. in the proceedings between Enron corporation ponderosa assets, 1.p (claimants) and Republic of Argentine (respondent) ICSID Case No. ARB/01/3. Award. Members of the Tribunal: Professor Francisco Orrego-Vicuña, President, Professor Albert Jan van den Berg, Arbitrator, Mr. Pierre-Yves Tschanz, Arbitrator. Secretary of the Tribunal: Ms. Claudia FrutosPeterson (2007) <http://italaw.com/sites/default/files/case-documents/ita0293.pdf $>$ accessed 19 January 2015. 